\title{
Reflective Dialogue: what's in it for teachers? A Pakistan Case
}

\author{
JANE F.A. RARIEYA \\ Aga Khan University, Pakistan
}

\begin{abstract}
Reflective dialogue is still very much an unexplored area in teacher education in Pakistan. This article presents findings of a study that engaged four teachers in the process of reflective dialogue in a school in Karachi, Pakistan. It explores the teachers' response to the process and possible reasons. It also examines the role played by those who help teachers to become reflective (reflective coaches). Findings indicate that reflective dialogue is an alternative teacher professional development strategy, and that a teacher's level of reflection is dependent on the teacher's commitment to teaching, personal reasons and responsibilities. Teaching experience also influences one's approach to reflective dialogue. It is also suggested that if successful, reflective dialogue empowers teachers by enabling them to take control of teaching and learning in their classrooms. The implications of reflective dialogue for teacher education in Pakistan and similar contexts are also shared.
\end{abstract}

\section{Introduction}

Reflection has become one of the key principles underpinning good teaching practice and teacher education. Calderhead \& Gates (1993, p. 1) have observed that 'it is frequently presumed that reflection is an intrinsically good and desirable aspect of teaching and teacher education and that teachers, in becoming more reflective, will in some sense be better teachers ...'. However, this tacit acknowledgement that teachers need to be reflective practitioners and the development of reflective practice has largely been in the West. Teachers in Pakistan and the rest of the developing world are generally unaware of what the term 'reflective practice' means. A number of those who know do not know how they can effectively engage in it.

Teacher training in Pakistan is, on the whole, 'relatively ineffective' (UNESCO Principal Regional Office for Asia and the Pacific [UNESCO 
PROAP], 2000, p. 20), leaving qualified teachers with limited understandings of both subject content and pedagogical skills. With an overemphasis on theory, there is little time for discussion of the very real challenges of the classroom, and little distinction is made between the needs of different schools and students. The primary teacher education curriculum 'suffers from a lack of contextual relevance' (UNESCO PROAP, 2000 , p. 20). Teachers often spend several years teaching before they receive formal training, and in fact there is little evidence to show that students of trained teachers perform any better than those of untrained teachers (O'Gara et al, 1999). This is not surprising given the fact that teacher educators in elementary teacher training colleges are often transferred there just before retirement, meaning they may have little interest in the training process. Outside of the major cities, professional development opportunities for teachers are rare and often of poor quality (Warwick \& Reimers, 1995). It is within this contextual background I conducted an exploratory study to find out how teachers in Pakistan, who have never been reflective practitioners, can be helped to become so through engaging in reflective dialogue.

This article begins with a literature review on the meaning and nature of reflective dialogue. It then looks at how reflective dialogue was conceptualised in this study as this determined the data collection methods and tools that were used. Brief profiles of the participant teachers are also shared because findings seem to suggest that who they were and what the teachers did at the start of the study partly account for their response to reflective dialogue. The role of the reflective coach and the possible impact of this role on the teachers' response are also explored. Their response to reflective dialogue is then described and subsequently analysed. Finally, the possible implications of the findings of the study for teachers and teacher educators in Pakistan and similar contexts are discussed.

\section{What is Reflective Dialogue?}

Attempting to define the term 'reflection' presents a challenge in itself. A large amount of literature is available on reflection and it is impossible to provide one definition of the term. Those who have dealt with the concept of reflection, whether they have focused on its philosophical origins or on its value in teacher education, have used somewhat different definitions of the concept (Zeichner \& Liston, 1996; DarlingHammond \& Snyder, 2000; Loughran, 2002). The literature contains many different explanations depending on which theorist the writer is drawing upon or which aspect of reflection is being emphasised.

A review of the various meanings that have been given to reflection in teacher education literature (Calderhead, 1987; Elliot, 1991; Francis, 
1997; Loughran, 2002; Serafini, 2002; Risko et al, 2002) indicate that engaging in reflection leads to:

- a new understanding of actions and situations;

- new understandings of oneself as a teacher in terms of the cultural, political and social environment of teaching;

- a new understanding of assumptions about teaching due to the critical stance one adopts;

- the development of the commitment and skill to take an informed action.

Reflective dialogue as a concept means different things to different people. Until now many researchers and writers have not used the term 'reflective dialogue' to describe their own activities or understanding. Instead, they use the terms, 'reflection', 'reflective practice', 'teacher talk' or 'teacher conversations' interchangeably. I, too, have used them interchangeably in this article, as I feel they encompass what reflective dialogue is. A review of literature and research (Stephens \& Reimer, 1993; Thomas \& Montemery, 1997; Risko et al, 2002; Serafini, 2002; Fendler, 2003) reveals that reflective dialogue is viewed either as the maintenance of a dialogue journal or participation in reflective conversations in groups or pairs. In the study, I used the term to include both the notions of dialogue journals and reflective conversations.

Certain features are peculiar to reflective dialogue and distinguish it from other forms of reflection. The first is that reflection is done through talk. This talk can be verbal or written as in the form of dialogue journals, which Holly (1994) describes as talk with oneself. However, if this talk is to be termed reflective dialogue, then it is talk shared with others by giving them access to one's thoughts in the journal to read and respond accordingly. So, reflective dialogue is not an individual activity but it is reflection with others who ask questions of one another, thereby helping each other gain new insights about situations, beliefs and values. Moreover, the perspectives are usually shared in an atmosphere of mutual support. Hence, collaboration is also a significant aspect of reflective dialogue.

Reflection usually resides in the mind of an individual and it is difficult to be directly observed. However, reflective dialogue helps to move reflection from the realm of private activity. The dialogue creates a level of understanding about the constraints of one another's practices and gives the teachers engaged in the reflective dialogue an opportunity to bring their expertise to an endeavour that is potentially enriching to all involved (Morrison, 1996).

Reflective dialogue provides 'windows' into teachers' thinking (Thomas \& Montemery, 1997), as it enables the teacher to open up his or her teaching to the public through writing or talk. Its value in teaching and learning is that it encourages one to view issues from different 
perspectives. Furthermore, when teachers learn to identify and articulate what they know about children, about learning and teaching, it can be seen as empowerment. This is because in engaging in a quest to understand their work, they take control of themselves and their professional development; they find their voices (Freire, 1972; Giroux, 1983; McElroy-Johnson, 1993).

\section{Nature of the Research}

The study employed a qualitative case study approach and engaged four teachers from the same school. None of the teachers was familiar with reflective practice or any of its related terms. My role in helping the teachers engage in reflective practice as a reflective coach was also under study. In this study, the term 'reflective dialogue' was used to include both the notions of dialogue journals and reflective conversations.

The data sources for this study included individual interviews, informal conversations, participant observation, classroom observations, personal documents, researcher journals and opportunities to engage in reflective dialogue.

Reflective dialogue took place at three levels:

- Each teacher maintained a dialogue journal, which she shared with me as the reflective coach throughout the study.

- Each teacher had a chance to engage in individual reflective dialogue with me after a classroom observation (one-to-one reflective sessions).

- All the teachers took part in a group reflective dialogue session once a week for 1 hour (group reflective sessions).

Though the teachers' response to the different forms of reflective dialogue was also a focus of this study, its findings have not been shared here as it is not the subject of this article.

Reflective dialogue focused on issues related to teaching, either with regard to the teachers' practice or thoughts about teaching, schoolrelated issues, personal issues, as well as the process of reflection that the teachers were undergoing.

Data analysis involved a cross-case analysis, whereby I not only looked at each individual participant as a single case, but also looked at all of them as a whole group. In so doing, I tried to draw individual responses to the study and eventually the implications of this on my understanding of my inquiry.

\section{Participants' Profiles}

Below are brief profiles of the research participants that I believe partly account for each individual teacher's response to the uptake of reflective dialogue: 
Shafia is a science graduate and at the time of the study had five years of teaching experience. In addition to teaching English, Mathematics and Science to class three, she was a class teacher and a housemistress. At the time of the study, she was a single woman who lived with her parents and had no family responsibilities. She seemed a busy woman, though all the activities she was engaged in were professional. For example, she taught at an English Learning Institute for two hours each day after school. She had a good reputation as a teacher both at the school and the institute and had won the best teacher award in the school the previous year. She had also been to a number of in-service courses/workshops and had learnt various teaching strategies, which she used in her classroom and which she felt had made her a better teacher.

Aliya, a political science graduate, had six years of teaching experience. At the time of the study, she had only been in the school for five months. In addition to being a class teacher, she taught social studies to classes four and five. At the time of the study, Aliya was engaged to be married and expected to give up teaching once married.

Maryam, who at the start of the study had only four months teaching experience, taught English to class seven. She was single, lived with her parents and had no family responsibilities.

Razia is a political science graduate and had five years of teaching experience. At the start of the study, she had only been in the school for five months. Razia taught social studies to classes six, seven and eight. She was divorced and lived with her parents and daughter. Being a single parent, she was solely responsible for bringing up her daughter.

\section{The Process of Uptake of Reflective Dialogue}

At the outset of the study, all the teachers had personal motives for engaging in reflective dialogue that, in turn, determined the nature of their approach to the process. For example, although Shafia engaged in reflective dialogue with some reservations, her participation in the study was influenced by her desire to stay at the top as the best teacher as is illustrated by the following entry from her journal:

I have been teaching for 5 years but still I'm afraid of observations and criticism. Maybe, it is because I want to prove myself the best one and I want to maintain my previous record [of being the best teacher].

On the other hand, Maryam's approach to reflective dialogue was influenced by her desire to not only fit into the school, but also to learn 
how to be a teacher, which she did not feel confident about because of her inexperience. She had this to say, 'At the moment, I'm just trying out my beliefs and assumptions and my learnings that I got at the university and after that I'll bring about modifications to my teaching'. Razia, like Maryam, did not exhibit any confidence in herself as a teacher and professed a desire to want to learn to be a teacher. She attributed this lack of confidence to her lack of formal teacher training and the teaching strategies that teachers were being encouraged to use in the school. She said, 'After joining this school, I think I don't know anything in teaching'. Aliya only participated in the study at the encouragement of the viceprincipal and viewed her career in teaching as short-lived, as she was engaged to be married and expected to give up teaching once married.

From the beginning, all the teachers seemed to be unfamiliar with the practice of reflecting on their lessons. For example, at our first reflective session, Maryam told me, 'At the moment I don't have any difficulties handling my students or classroom. My teaching, I believe, is okay'. Shafia, on the other hand, told me, 'Maybe I need no improvement'. While for Razia, 'everything went well, according to my satisfaction. I don't think there's any change that I should make to whatever I did in the classroom'.

In order to enable the teachers to look critically into their classrooms, my role as a reflective coach took on different dimensions as the study unfolded. This multifaceted role that I played is perhaps an indication of the nature of support that teachers in this context need from a reflective coach. Thus, as a result of the teachers' initial stance about the quality of their teaching, I had to ask questions in order to make them question what had happened in their classrooms, as well as discuss alternate ways of doing what they had done in class. This met with resistance and they often demanded evidence of what I perceived to be weaknesses because of the suggested alternatives. For example, I urged Aliya to seek alternative sources of information, including using her students as sources of information, instead of wholly relying on the textbook. She disagreed, and argued that the students could not do anything on their own and stated, 'How can they know? They are children. It is my duty to tell them'. In addition, she felt, 'That which is in their text books is enough for them. At their level, that is enough'. Razia was more emphatic about not seeing things from another perspective. She argued that there was no need for her to teach differently, 'because the students are used to learning the textbook by heart and soul through questions and answers and that is how teachers are used to preparing their lessons. So, if you bring an immediate change to their routine, they'll be confused. And anyway, any changes in teaching should be done right from class one, not here in class six'.

Though Elliot (1991) suggests that those who support teachers must relinquish their 'expert' role, I found this to be impossible in this context. 
It became evident to me that the teachers, with the exception of Shafia, knew no alternate teaching strategies and had no idea how the ones I suggested could work. For example, at the start of the study, Aliya's lessons were characterised with students memorising and regurgitating what was in the textbook. The questions she asked of the students were close-ended and only encouraged interaction between her and the students, with the students responding to her. She saw nothing questionable about this kind of teaching and maintained 'I managed to teach what I had planned. As long as I do what I have planned for the students, that is the important thing'. Later at a reflective session she succinctly stated:

Najma [section-head] always says, 'Don't use these methods.

We want some modern methods. When they [school administration] told me this the first time, I wondered when and how I will do this. I don't know any new modern techniques. If they want us to do these things, then they should conduct some workshops and tell us how to use those techniques in our classrooms and when we can use them.

I was therefore compelled to model some lessons and even share some reading material on areas that were of interest to some of them, such as group work and questioning strategies. The modelling served to shift the teachers' stance about 'looking' into their classrooms. For example, when Shafia saw that some of the ideas I suggested were feasible, she began to try them out in her classroom. It was then that she began to think about the effects of her teaching on her students. She later remarked at a reflective session:

I've learnt that I can arrange my students in groups, but in the past I always arranged them so that they can only do the work I have given them. My basic target was they should complete the task and in the right way. Sometimes, I ignored their social skills so that often they would shout. I would only ask them to keep quiet so as to have a quiet environment, and also because I didn't want anybody coming to my classroom wondering what was wrong with the class.

Aliya, on the other hand, after observing me teach her students by overtly using their prior knowledge on a given topic, said:

I did not know my students know so much and that they can talk. They never talk to me the way they did when you were teaching. I think this is a good way. In my previous lessons, I used to explain to them everything and when I found that they could not answer my questions, I would tell them. 
Maryam, as a result, took up my suggestions and tried them in her class. She began to notice that some of them seemed to have a positive impact in her classes. For example, she once remarked, 'I'm beginning to see a change in my students. They are more active in class'. This seemed to have a corresponding effect on her attitude for she said at one of the reflective sessions, 'I really had a positive response yesterday as well, so I had a positive attitude today when I walked into class'.

However, this shift in the way they looked into their classrooms was not instantaneous upon lesson demonstrations or suggestions of alternatives. The teachers had certain concerns that they felt were not readily addressed by looking critically at their classrooms or thinking of better ways to do things. For example, when we started our reflective sessions, Aliya did not seem bothered about her teaching or her students' understanding or lack of it. Her focus was on how to write a lesson plan that was a requirement of the school. She was constantly reprimanded by her section-head for her 'poorly written' lesson plans. 'I don't know what to do. I can explain the topic which I'm teaching in the classroom, but how can I write what I'm going to do in the classroom?' was her constant query at the reflective sessions. Her struggle to survive in the school obstructed her from reflecting on her teaching. I, therefore, had to teach her how to write a lesson plan before we could concentrate on critically reviewing what had gone on during her lessons. With each succeeding reflective dialogue session, Razia would maintain that the students had 'perfectly understood' whatever she had taught and would constantly tell me. 'I have to complete my monthly syllabus'. At the beginning of the study, Maryam's inability to reflect critically and therefore take risks and change or improve her classroom practices were kept in check by the school regulations about what form the students' learning should take. She said:

What bothers me is that whoever is in charge won't find anything in the students' copies [notebooks] and I'll be asked what I did in that particular period. These are the things that bother me because they'll ask me why I did not stick to the book. I have to have something in the books, though I don't think that it is really necessary.

Shafia, too, cited her demanding workload and lack of support from some of the school's administrative personnel and her colleagues as some of the impediments she had to contend with in her attempts to be a reflective teacher.

With the exception of Razia, a shift became evident in the nature of the teachers' engagement with reflective dialogue over time. For example, Shafia began to reflect not only on her lessons with me by responding to my questions, but would also do so on her own during her lessons. She began to become alert to the effects of her teaching on herself and her 
students. For example, after a lesson, which I had observed, she told me this about the lesson:

Sometimes during the lesson, I felt it was going on very well. The students were participating but sometimes things were not going well. Like when I gave the questions to the students, I gave them the responsibility to ask questions of each other. I have not done this before and I found myself feeling a little confused, just as they were ...

This shift in the teachers' level of reflection was accompanied by a heavy dependency on me. They would discuss every minute detail of their lessons with me, seek my opinion on various issues, request literature on things they wanted to know, and so forth. Hence, they no longer were passively engaged in reflective dialogue. They became quite active and for Shafia this activeness did not flag throughout the rest of the study period. However, they still needed prompting and probing to critically think of their classrooms and think of ways of improving events in their teaching. The following excerpt is an illustration of Aliya's inability to think further on how to improve things in her classroom:

$A$ : In this section [class] that you observed, the students have a lot of language problems. When I want to tell them something, I have to really think of how I'm going to explain it. It's so frustrating. How do I do this?

$R C$ : And the other sections [classes]?

$A$ : The other two sections are a little better. They respond well in class. The ' $\mathrm{B}$ ' section in particular is very good. They were even able to tell me the names of the countries where the wonders were. But in this section, I always feel frustrated. What should I do for them?

$R C$ : Is it that they don't know or is it that they don't make any effort?

$A$ : Both.

$R C$ : So, what are you going to do now?

$A$ : I don't know. What can you suggest?

Along with an improved engagement with reflective dialogue, came doubts about their effectiveness as teachers and during this time the teachers seemed only interested in the things that went 'wrong' in the classroom. This was because they realised that becoming reflective and thereby improving on one's practice posed certain challenges. For example, after one lesson, Aliya said:

I have to read again. You see some children were talking about Antarctica and things like that which I am not aware of or clear about. You were there and you helped quite a bit. But I have to 
find out for myself and prepare myself. I think maybe I am not giving them enough information. I am not teaching well.

Hence, she began to spend more time in the library reading up on the topics that she was going to teach and would ask me a lot of questions, either on the topics or on how to teach them. In the case of Shafia and Maryam, I had to continually support them by identifying some of the good things that were happening in their classrooms as illustrated in the following excerpt of a reflective dialogue between Maryam and me:

$R C$ : How do you think that activity went?

$M$ : I should have begun with a review instead of just starting off from where we left.

$R C$ : Why do you think so?

$M$ : Because a lot of time was wasted because of reminding some of them what we had discussed. I don't know but when I think that I have just got it right then I still do the things we had said were not right. I don't know, I don't think I can really be a good teacher.

$R C$ : What about the students' involvement? Don't you think that when the class got going, everybody was involved and the answers they gave were interesting and humorous too? I think we need to discuss the good things that happened and try to see why they happened ...

Razia, however, made no shift whatsoever in her engagement with reflective dialogue. She taught in the same manner that she had been doing at the beginning and maintained that she had to complete the syllabus to whatever suggestions her colleagues or I had to make. Eventually, she dropped out of the study because she claimed that she was not comfortable with the process of reflective dialogue. 'I don't know why it is so, but I'm not feeling comfortable', she said at a group reflective session. In addition, she felt that her demanding workload and family obligations made it impossible for her to engage in any form of reflective dialogue. She said:

You are telling me to try this and try that in my class and that means that I have to carry my work home. That is extra work for me. I am not used to this. I just can't. I don't have the time. I am divorced. I have a baby daughter and when I go home, she is my responsibility. I also have to help with the work at home. So, how can I write in my journal?

Despite the aforementioned doubts, the teachers at this stage felt that they were learning something though they were had put to exactly pinpoint what effect reflective dialogue was having on them or their 
classes. For example, all Shafia could say was, 'I'm learning. How can I say what I'm learning? I can feel within myself that I'm learning'.

As the teachers began to look critically at their lessons, the focus of their reflections expanded. It extended to the process of teaching, structures in the school, the role of parents and society at large in education, as well as understanding themselves personally and professionally. For example, Shafia told me, 'before your coming here, maybe I knew how to teach but now I think about it. Why has it happened to me? Why is it happening here? How should I remove that thing from my teaching?' Aliya, on the other hand, made the following entry in her journal:

I wonder what can be done about my students? They do not do their homework at all. What do the parents do? I am always surprised at how the parents seem to think that as teachers we can help their children without support. If the students fail, I'm blamed. How can I make these parents see that they need to help their children at home ...

As the study drew to a close, Shafia's growth as a reflective teacher was marked by her eventual ability to ask questions of her own teaching without my necessarily having to ask her questions that would enable her to think critically about the lessons. For example, during a reflective dialogue session after a lesson I had observed, she turned round and asked, 'By the way, what do you think about the question I gave them about choosing the best moral of the story?' She went on before I could say anything, 'They were confused there. I think that next time I should make the choices of answers very different from each other, instead of what I did today'. It was then that she began to draw on some of the techniques she had learnt at the in-service courses/workshops. She would also share some of these alternatives with her colleagues during the group reflective sessions. However, throughout the study, Aliya demonstrated an inability to come up with alternatives other than those I had exposed her to. So Aliya ended up perfecting these techniques and thus her classroom practice improved. Her attitude towards her students also changed. She said:

You see, in the past, I used to go to class, give a lecture and the students would keep quiet and listen to me. But now, I ask them to talk, to tell me things ... I used to think that they don't know anything but they know something. I want this type of class where the students respond to me.

Though Maryam became actively engaged in reflective dialogue, and would look at the things that went well or did not go well in her classroom, she also began to see the role she played in not developing her students' understanding of whatever she taught. This was a departure 
from her previous attitude when she had felt that her students' lack of understanding was through no fault of hers. Once during a reflective session after a lesson I had observed, she said:

You know what? I do realise I made a mistake. I had thought that since I had already explained the exercise using daily life examples, I would be repeating myself. So, I went on to teach directly without realising that it is probable that they would not remember all that.

By the time the study drew to a close, Maryam still lacked the ability to look 'penetratingly' into her classroom without probing or leading questions from me as the following excerpt shows:

$R C$ : Now, tell me about your instructions to the students?

$M$ : Were they not clear?

$R C$ : How were you supposed to give them?

$M$ : Yes, I found myself giving instructions in the middle of the activity. In fact, when one of the groups had already done their work in the wrong way. I should have done that at the beginning.

Reflective dialogue did not only open up the teachers' classrooms to scrutiny by themselves, their peers or me, but also in some instances, by their students. Some of the teachers did not mind their students evaluating their teaching because they saw this as an opportunity to improve it. For example, Maryam asked her students at the end of the term to share with her in writing what they liked or did not like about their English lessons and what they would like to do in their lessons that they were not already doing. This was a departure from their feelings at the start of the study when the teachers had thought that they were good teachers, and had never asked their students' opinions or anyone else's for that matter about their teaching.

\section{The Reflective Coach}

I played the dual role of a researcher and a reflective coach, both of which had an impact on the teachers' capacity to engage in reflective dialogue. However, it is my role as a reflective coach that I wish to examine in this article.

Reflective dialogue necessitates the presence of the other person who responds to the teacher's reflections, thereby facilitating the process of reflection. Thomas \& Montemery (1997) talk of 'reflective coaching' (p. 380), which they describe as the role one plays in posing thoughtprovoking questions to help the process along and points out that teachers need these kinds of reflective coaches. 
My role as a reflective coach took different dimensions depending on which form of reflective dialogue I was involved in. In order to have a reflective dialogue session with an individual teacher, I would observe the teachers' lessons and then we would critique the lessons together. In this type of reflective dialogue, I found myself playing a very active role, in fact, almost dominant, especially at the beginning of the study because of the teachers' lack of apparent readiness to reflect on their teaching. I asked most of the questions, suggested alternatives, provided reading materials and sometimes modelled some teaching technique. I had to be careful how I did this because I did not want to alienate the teachers. Also, changing one's beliefs and assumptions, especially if they have been long held, is neither easy nor comfortable. I felt that the teachers would need my support as they organised and reorganised their orientations about teaching. How I did this was viewed differently by individual teachers. One said, 'I like the way you tell me my weaknesses ... The manner in which you tell me my weaknesses is good. I never feel threatened'. Yet, another said, 'how can you feel there are mistakes in my lesson? I have been teaching for five years and nobody has ever made me feel that my teaching was not up to standard'. As the study progressed, I found that I had to reduce the intensity of the classroom observations for I felt that this would help me see whether the teachers were able to reflect on their own.

During the group reflective dialogue sessions, I did not really come to the foreground as in the one-to-one sessions. Maryam said of my role during these group reflections, 'You were there as an observer ... You sort of had a backseat over there and we were the main people discussing things there'. Right from the start, I had made it clear that it was the teachers' session and they had to do most of the talking. This is because I felt that the teachers needed to be made to speak up, with the hope that they would learn to critique my views during the one-to-one reflective sessions. Nonetheless, in addition to taking care of the logistics of these sessions, I initiated the reflective process, co-ordinated the tempo of the dialogue, as well as ensured that all the members participated in the session. I had to constantly ask questions of the teachers to raise the level of the dialogue to a reflective one and not just mere descriptions and complaints about whatever happened to be the issue under discussion.

As for the journal writing, my role was that of responding to the teachers' entries. My responses would range from asking questions to raising the teachers' thinking about some of the issues they had written about, to commiserating with them about something, to praising them and even sharing my experiences as learning points or just showing plain appreciation for some of the things they had done or were doing in their classrooms. Responding to the teachers' entries seemed to enhance the 
depth of their reflectivity as well as their commitment to maintaining their journals. As Shafia said:

When I first wrote in my journal, I had thought that you'd only take it and just read it. But when you wrote some remarks and it struck me that somebody has responded to what I had written, at that time I started to write more seriously. It was not that I wanted to please you but I felt that there was someone who was taking note of my problems, someone who could help me when she read my journal.

To help me enact my role as a reflective coach, I found I had to ensure that the teachers' perceptions of me did not assume 'god-like' proportions and the status of an expert in teaching because of the fact that I came from an institute that is renowned for its innovative and quality programmes in teacher education in Pakistan. So to constantly remind them that I was a learner just like them, I allowed the teachers to see my moments of uncertainty by inviting their opinions about issues related to my teaching. I also encouraged them to question some of the things that I said and did. I made it clear that they could accept or reject my suggestions.

There are several reasons why the teachers, with the exception of Razia, were willing to accept my role. First, as has been mentioned, I came from a Teacher Education Institute that qualified me as an 'expert' in their eyes. This was a view that emanated from the school administration and on numerous occasions the administration sought my opinion on several things that were going on in the school, especially with regard to the teachers. Secondly, the teachers felt that I had close links with the administration and therefore everything I did had the administration's seal of approval. Not cooperating with me would have reflected poorly on them and it did, as in the case of Razia. She told me at the end of the study:

When I stopped being part of your group, everybody here including the bosses [administration] thought that I was bad and that I did not want to learn. They were all talking about me and asking why I didn't want to be part of the group while the other teachers [participant teachers] are saying they are learning many things.

Thirdly, the teachers felt that since I was there only for a short while, they could put up with my presence. At the first group reflective session, one of them stated, 'I don't mind the extra burden of working with [the author]. I am accepting all these discomforts because it's only for this term'. Fourthly, over time, the teachers and I developed a relationship of trust and I believe this helped the teachers realise that I would neither publicise their weaknesses as they let me into their classrooms nor reveal 
some of the things they told me in confidence. One of them even told me, 'When I met you, I felt that I could tell everything. I really share some things that I would never share or discuss with anybody else'.

Table I illustrates the different levels of reflections that the teachers moved along during the process of engaging with reflective dialogue. It also shows the final level that each individual teacher was at by the time the study came to a close. The role the reflective coach played at the different levels of reflection is indicated in the table too.

\begin{tabular}{|c|c|c|c|c|}
\hline \multicolumn{2}{|c|}{ Level of reflection } & \multirow{2}{*}{$\begin{array}{l}\text { Representation of } \\
\text { reflection } \\
\text { Restructured learning } \\
\text { and able to see its } \\
\text { applicability. Issues } \\
\text { looked at both the } \\
\text { micro and macro } \\
\text { levels. Issues looked at } \\
\text { from various } \\
\text { dimensions - ethical, } \\
\text { moral, political, etc. } \\
\text { Rationale and purpose } \\
\text { of actions and beliefs } \\
\text { given. }\end{array}$} & \multirow{2}{*}{$\begin{array}{l}\text { Role of } \\
\text { reflective } \\
\text { coach }\end{array}$} & \multirow{2}{*}{$\begin{array}{l}\text { Individual } \\
\text { placement } \\
\text { at end of } \\
\text { study } \\
\text { Shafia }\end{array}$} \\
\hline 5 & Transformative & & & \\
\hline 4 & Making meaning & $\begin{array}{l}\text { Meaningful reflections, } \\
\text { able to identify } \\
\text { purpose. Explanations } \\
\text { with principle or } \\
\text { theory given as the } \\
\text { rationale. Can also } \\
\text { identify issues at the } \\
\text { macro level. }\end{array}$ & $\begin{array}{l}\text { Listen actively. } \\
\text { Share } \\
\text { resources, e.g. } \\
\text { reading } \\
\text { materials. Ask } \\
\text { an occasional } \\
\text { question. }\end{array}$ & \\
\hline 3 & Making sense & $\begin{array}{l}\text { Critical incidents are } \\
\text { described, but not } \\
\text { analysed. Events are } \\
\text { appropriately referred } \\
\text { to. Discomfort and } \\
\text { uncertainty about the } \\
\text { process. Occasionally } \\
\text { raises macro issues. }\end{array}$ & $\begin{array}{l}\text { Ask probing } \\
\text { questions. } \\
\text { Listen. } \\
\text { Scaffold. } \\
\text { Highlight } \\
\text { strengths. }\end{array}$ & $\begin{array}{l}\text { Maryam } \\
\text { Aliya }\end{array}$ \\
\hline
\end{tabular}


Jane F.A. Rarieya

2 Noticing

Simply outlines the strengths and weaknesses of lesson taught. Skeletal wording. Focus is only on the classroom.

1 Unawareness

\author{
No queries raised. No \\ critical incidents \\ identified. A general \\ satisfaction with \\ things as they are.
}

Dominant.

Shares alternatives. Model lessons.

Ask questions

Quite
dominant. Askia
questions.
Share
alternatives.
Model lessons

Table I. Levels of reflections and corresponding role of the reflective coach (an adaptation of Bax \& Cullen's (2003) table on the Stages of Learning during a teacher's adoption of reflective practice.

\section{Discussion}

The teachers' growth as reflective practitioners seems to suggest that a teacher's ability to engage in reflection for improvement is possible and will sustain when the teacher is open-minded, wholehearted, responsible, willing to take risks and has access to alternative ways of teaching.

All the teachers exhibited different levels of reflection despite the fact that they were all exposed to similar reflective dialogue opportunities with the same frequency. Maryam and Aliya's reflections, unlike Shafia's, did not develop to the stage where they could question any of the suggestions I made. Shafia, unlike her two colleagues began to take action about certain administrative requirements that she felt inhibited her students' learning, especially with regard to the syllabus. She remarked at a reflective session, 'I have stopped teaching what I have to teach. I now teach what is beneficial to my students'. I can only attribute these differences in their levels of reflection to their commitment to teaching and to a certain degree, their responsibilities. Shafia was a committed teacher who wanted to improve and this affected the way she embraced reflective dialogue. Maryam was new to the profession and was still trying to find her way in the teaching world. Her mind seemed focused on how she could do this. Aliya only saw her time in teaching as temporary and was therefore only interested in what could enable her to survive in the school. Razia too was not committed to teaching for she claimed that family responsibilities did not allow her to engage in extra work related to the profession. Aliya and Razia's responses confirm Calderhead's (1987) view that teachers who are not committed to dealing with educational problems or whose commitment is partial and limited are unable to realise their full reflective potential. However, at the same time, in 
working with a teacher like Razia, I realised the importance of being cognisant of the fact that teachers' personal and professional lives are closely intertwined. Razia was not willing to engage in reflective dialogue because of her personal problems and perhaps the pace of the study was a drawback in that Razia and I did not have time to reflect on her personal problems, which no doubt had an impact on the kind of teacher that she was. Indeed, in Pakistan, as is common in many other countries, teachers' lives cannot easily be divided into neat parcels of in-school and out-of-school teacher identities (Kirk, 2003).

It is also possible that the gender of the participants did have an impact on the way they responded to reflective dialogue. As Farah \& Bacchus (1999) point out, in Pakistani society, perceptions of women are connected to their role within the family and within the home. This could probably account for Aliya's decision to drop out from teaching once she got married. Kirk (2003) in her study of women teachers in Karachi, Pakistan found that even though her participants considered teaching a suitable profession and one which they could combine with other responsibilities, their lives was one of constant negotiation of a comfortable and feasible balance between home and school activities; and this in itself presented a challenge to them. Razia seemed to have found this balancing act difficult to manage and hence opted to drop from the study. However, reflective dialogue ordinarily is flexible enough to allow teachers to reflect on both their personal and professional lives. This could possibly lead to teachers who have better control of their lives both in and out of classrooms.

By the time the study drew to an end, the teachers found that reflective dialogue is a process of continual learning and that it had led to both their professional and personal growth. As Shafia pointed out:

I learnt so many things which were related to my teaching and to myself, but being able to assess myself as a teacher is what I can say was the most beneficial to me ... Because of being able to assess myself, I began to feel that I did not know a lot of things and you see the process of learning is still going on within me. I have learnt a lot of things, I am learning and I know I will continue to learn.

Aliya had this to share:

I learnt a lot of things. As you know, I am very new in this school and I was having problems adjusting to the language and teaching used here. I had not been to any workshop but since I started reflecting with you, I've got new ideas, new techniques of teaching. Now, I'm even beginning to enjoy teaching. 
Maryam on the other hand found that reflective dialogue was a learning experience, albeit a gradual one. She said:

It was not a conscious learning. It was a learning that was done unconsciously. I was learning things, not in an official manner but what I learnt was coming to me through our talking together. It was a kind of awareness. Our talking together and with others sometimes created an awareness within me that there are things I can think about my class.

On the personal front, the teachers felt that their personality had been altered to a certain degree as a result of engaging in reflective dialogue. Shafia said:

One thing is that I have now developed some tolerance. Before you introduced me to reflective dialogue, I had this bad habit of rejecting people's ideas. I always felt that I knew better and would dismiss people's ideas, especially if they were my juniors in teaching.

About her personality, Aliya had this to say:

I have become more confident. Also, because of talking to you and the others in a group, I found I was able to speak up without fear and I have learnt to listen to what people are saying and see how it can help me.

Even though the study shows that the presence of the 'other person' is essential in helping teachers to be reflective about their teaching, the teachers in the study had differing views about my role as a reflective coach. Whereas Aliya felt that she had begun to seriously think about her teaching because, 'it was the first time somebody had asked me about my teaching', Razia viewed my presence in her class as a 'silent questioning' of the things that went on there and felt that I was silently criticising her. She told me, 'You would come to my class and write and write and say nothing. I am not used to somebody sitting in the classroom and looking at me teach'. Regardless, of the conflicting perceptions indicated in the foregoing, the role played by the reflective coach is important because, 'one cannot assume that teachers will explore issues or challenge their thinking on their own' (Dobbins, 1996, p. 276).

\section{Implications of Reflective Dialogue for Teacher Education and Teacher Educators}

It needs to be emphasised that this study was of a relatively small sample. Therefore, findings must be taken as suggestive rather than conclusive.

There is acknowledgement that teachers need to be active participants in educational change processes. As the 'Expanded 
Commentary' of the Dakar Framework for Action (World Education Forum/UNESCO, 2000) states:

Teachers are essential players in promoting quality education, whether in schools or in more flexible community-based programmes; they are advocates for, and catalysts of, change ... Teachers at all levels of the education system should ... have access to training and on-going support ... and be able to participate, locally and nationally, in decisions affecting their professional lives and teaching environments. (p. 20)

It is therefore imperative that in-service courses in Pakistan be available to all teachers because a majority of schoolteachers are not teacher trained. In addition, if these courses are to actually enable the teachers to learn and therefore grow in their profession, they should develop in teachers the disposition to interrogate their unidentified knowledge about their practices. Without this, the teachers are more likely to be engulfed by the demands of teaching as usual and less likely to interrogate the ways they read and experience their practice. In a developing and changing society like Pakistan, children and parents are entitled to teaching that is based on reflection. Fullan et al (1990) suggest that if classrooms are to become communities of active and inquiring learners, teachers who provide the leadership and guidance in such classrooms must themselves have professional development that is also inquiry-orientated and collaborative. For example, in this study, by engaging in reflective dialogue, the teachers learnt how to identify and articulate what they knew about their students, learning and teaching. Hence, by engaging in a quest for an understanding of their work, they were taking control of themselves and their professional development.

One of the main points that the teachers repeatedly emphasised about reflective dialogue was its integration with their real world and the actuality of classroom life. They emphasised the practical nature of reflective dialogue as they applied its outcomes in their classrooms. It addressed their practice problems. This, therefore, led the teachers to develop a positive attitude (with the exception of one) towards reflective dialogue. This seems to suggest that teachers' professional development here in Pakistan needs to have a reflective and practical approach arising from the actual classroom situations as experienced by the teachers. In the study, Shafia, who had been to numerous in-service activities, did have exposure to alternative ways of teaching, but she could not use these teaching strategies effectively because she lacked the ability to analyse critically how these teaching strategies could be improved upon and used effectively in her class. On the other hand, the rest of the teachers in the sample could think of no alternatives to what they were doing in their classrooms because they had no exposure to these alternatives. When all of them began to reflect on their teaching and were 
also exposed to different ways of doing things in their classrooms, they found that they improved enormously as teachers.

Furthermore, the study suggests that any effort to promote reflective dialogue in Pakistan schools will benefit from any training teachers can be given that helps them develop sensitivity to their ways of looking at and talking about teaching and developing a positive attitude towards questioning their teaching from themselves and others.

The teachers in the study stressed the importance of the reflective coach in helping them to develop the inclination to reflect and they all felt that this process would not have happened without the presence of the reflective coach. This seems to suggest that teacher educators need to be trained to work from within the classrooms, rather than concentrating on organising in-service workshops only or working out of school. This role is multifarious and relates to the suggestions made by Elliot (1991), Ashcroft (1992), Dobbins (1996) and Thomas \& Montemery (1997) among others, who point out that reflective coaches should not only be experts and reflective practitioners, but when necessary, they should adapt partnership roles as facilitators and collaborative learners.

It also seems that there is need to have a national policy that recognises both in-school and out-of-school teacher development activities. At the moment, most teacher educators work out of school, but this study reveals that an in-school teacher development approach is also fulfilling for teachers. Such a national policy would positively influence schools' expectations of teachers' professional development. Current teacher development activities concentrate on quantity and assume that quality is a natural outcome of these activities. In contrast, reflective dialogue as a teacher development strategy focuses on quality. This is because in the usual out-of-school teacher development activities, the teacher and the training are in the foreground, but in reflective dialogue the classroom is in the foreground and teacher improvement is ongoing. Thus, in reflective dialogue, improvement in classroom practice is a natural outcome of teachers' professional development. This suggests a strong link between reflective dialogue, teacher development and school improvement.

Whilst teachers, and women teachers in particular, in Pakistan, may currently be the subject of policy attention, they are often marginalised within educational structures and processes. As more female teachers are recruited into the teaching profession, those who work with teachers need to recognise that professional development opportunities for teachers may clash with their own family commitments, and their more active participation in education may be difficult to reconcile with family and social expectations. Indeed, Halai (1999) identifies heavy pressure from family commitments as well as insubstantial subject knowledge (women teachers are reported to have scored below men in teacher 
capability tests in Mathematics and General Studies [UNESCO PROAP, 2000]) as factors that inhibit the success of women as teachers.

Finally, one implication for teacher educators presents itself in the form of a dilemma. Taking into account the existing working conditions for teachers in Pakistan, for example, heavy teaching load, lack of resources, bureaucratic organisational structures among others and the time a reflective approach to teaching demands, the extent to which this reflection is expected to occur regularly without changes in the conditions of work for teachers is a major issue.

\section{Conclusion}

The study reveals that teachers in Pakistan can be reflective about their teaching if given the opportunity and equipped with the skills to do so. The teachers attributed numerous benefits to their involvement in reflective dialogue, which were not only manifested in their classroom practice, but also on their personalities. Hence, it can be suggested that in the absence of sufficient reflective ability, the teacher will not be able to bring his or her knowledge to the appropriate professional level.

However, as demonstrated by the study, learning to reflect is a developmental process and this is likely to raise several issues for both teachers and teacher educators. The paradox of engaging in reflective dialogue is clearly illustrated in this study. Although in becoming reflective about their work and, hence, the participants' awareness of their teaching was heightened, the process was one that required considerable effort, time and commitment for both the teachers and the reflective coach. This seems to suggest that in a context like Pakistan, teachers would have to be supported a lot to engage in this practice. Since dialogue is central to the process of reflective dialogue, teachers need opportunities during their training to be inducted into this kind of professional discourse. From the study, it seems that teaching from a reflective stance is something teachers are helped to become rather than instructed to do. Thus, when we encourage teachers to reflect on their learning, we need to enable them to determine and appreciate the functions, processes and reasons for reflection. The reflective coach, in turn, needs to consider the structures that need to be put in place to assist the practice of reflection, as well as carefully analysing the professional and social contexts in which teachers work and in which they are expected to engage in reflective dialogue. The study also demonstrates that reflective dialogue can provide the necessary nudging and coaching required to lead to more in-depth considerations about one's teaching

In a context like Pakistan, where the quality of teacher training and its corresponding outcomes are questionable, reflective dialogue is definitely an alternative professional development strategy for teachers. 
Jane F.A. Rarieya

Correspondence

Jane F.A. Rarieya, Aga Khan University-Institute for Educational

Development, 1-5/B-VII, F. B. Area, Karimabad, PO Box 13688,

Karachi-75950, Pakistan (jane.rarieya@aku.edu).

\section{References}

Ashcroft, K. (1992) Working Together: developing reflective student teachers, in C. Biott \& J. Nias (Eds) Working and Learning Together for Change, pp. 33-45. Buckingham: Open University Press.

Bax, S. \& Cullen, R. (2003) Generating and Evaluating Reflection through Teaching Practice, IATEFL Teacher Development SIG, 1, Spring, pp. 13-20.

Calderhead, J. (1987) Exploring Teachers' Thinking. London: Cassell.

Calderhead, J. \& Gates, P. (Eds) (1993) Conceptualising Reflection in Teacher Development. London: Falmer Press.

Darling-Hammond, L. \& Snyder, J. (2000) Authentic Assessment of Teaching in Context, Teaching and Teacher Education, 16, pp. 523-545.

Dobbins, R. (1996) The Challenge of Developing a 'Reflective Practicum', AsiaPacific Journal of Teacher Education, 24, pp. 269-280.

Elliot, J. (1991) Action Research for Educational Change. London: Open University Press.

Farah, I. \& Bacchus, K. (1999) Educating Girls in Pakistan: tensions between economics and culture, in F.E. Leach \& A.W. Little (Eds) Education, Cultures and Economics: dilemmas for development, pp. 225-237. New York: Falmer Press.

Fendler, L. (2003) Teacher Reflection in a Hall of Mirrors: historical influences and political reverberations, Educational Researcher, 32(3), pp. 16-25.

Francis, D. (1997) Critical Incident Analysis: a strategy for developing reflective practice, Teachers and Teaching, 3, pp. 169-188.

Freire, P. (1972) Education for Critical Consciousness. London: Sheed \& Ward.

Fullan, M., Bennet, B. \& Rolheiser-Bennett, C. (1990) Linking Classroom and School Improvement, Educational Leadership, 47, pp. 13-18.

Giroux, H. (1983) Theory and Resistance in Education: a pedagogy for oppression. Amherst: Bergin \& Garvey.

Halai, N. (1999) Non-cognitive Factors Vital for Women Returning to Education, in Working Group for Women, Aga Khan University (Ed.) New Directions in Research for Women, p. 44. Karachi: Aga Khan University.

Holly, M. L. (1994) Keeping a Personal Professional Journal. Victoria: Deakin University Press.

Kirk, J. (2003) Impossible Fictions? Reflexivity as Methodology for Studying Women Teachers' Lives in Development Contexts, unpublished doctoral thesis, McGill University, Montreal.

Loughran, J.J. (2002) Effective Reflective Practice: in search of meaning in learning about teaching, Journal of Teacher Education, 53, pp. 33-43. 
McElroy-Johnson, B. (1993) Giving Voice to the Voiceless, Harvard Educational Review, 66, pp. 85-104.

Morrison, M. (1996) An Examination of the Development of Teachers' Reflective Practice, Education Today, 46(2), pp. 43-47.

O'Gara, C., Benoliel, S., Sutton, M. \& Tietjen, K. (1999) More But Not Yet Better: an evaluation of USAID's programs and policies to improve girls' education. Washington DC: USAID.

Risko, V., Vukelich, C. \& Roskos, K. (2002) Preparing Teachers for Reflective Practice: intentions, contradictions, and possibilities, Language Arts, 80(2), pp. 134-144.

Serafini, F. (2002) Reflective Practice and Learning, Primary Voices K-6, 10(4), pp. 2-7.

Stephens, D. \& Reimer, K. M. (1993) Explorations in Reflective Practice, in L. Patterson, C.M. Santa, K.G. Short \& K. Smith (Eds) Teachers are Researchers: reflections and action. Newark, DE: International Reading Association.

Thomas, J.A. \& Montemery, P. (1997) On Becoming a Good Teacher: reflective practice with regard to children's voices, Journal of Teacher Education, 49, pp. 372-380.

UNESCO Principal Regional Office for Asia and the Pacific (UNESCO PROAP) (2000) Increasing the Number of Women Teachers in Rural Schools. Bangkok: UNESCO PROAP.

Warwick, D.P. \& Reimers, F. (1995) Hope or Despair? Learning in Pakistan's Primary Schools. Westport: Praeger.

World Education Forum/UNESCO (2000) The Dakar Framework for Action: education for all: meeting our collective commitments. Available at: www.unesdoc.unesco.org/images/0012/001211/121147e.pdf

Zeichner, K.M. \& Liston, D.P. (1996) Reflective Teaching: an introduction. Mahwah: Lawrence Erlbaum. 
